\title{
COMMISSION 22: METEORS AND INTERPLANETARY DUST (MÉTÉORES ET LA POUSSIÈRE INTERPLANÉTAIRE)
}

\author{
Report of Meeting
}

President: R. E. McCrosky.

SECRETARY: W G. Elford.

The business meeting was called to order at 15.15 on 24 August 1973. Nine members and two guests were present. The President was in the chair. He reported with regret the deaths of $\mathrm{Dr}$ Guigay of France and Professor Fesenkov of the USSR.

\section{REPORT}

The new format of the report has been generally favorably received. Two adverse comments were noted. The President pointed out that the discontinuance of the draft report procedure had made possible more up-to-date reporting, but as a consequence there was no way of reaching a consensus in the case of any disagreement. It was agreed that the new procedure was to be preferred. The current report was accepted.

In reply to a question from the Executive regarding future reports, it was agreed that;

(1) Reports are of scientific value, are used for reference purposes by members and should be continued in their present format.

(2) The Executive seek a less expensive form of publication.

\section{NEW OFFICERS}

The Executive Committee announced the appointments of B. A. Lindblad as the new President and I. Halliday as the new Vice President. The slate for the new Organizing Committee was accepted. The members are: A. F. Cook, W. G. Elford, T. R. Kaiser, L. Kresak, B. J. Levin, R. E. McCrosky and $F$. F Verniani.

\section{NEW MEMBERS}

The following were welcomed as new members of Commission 22: B. L. Kashcheev, V. N. Lebedinets, J. A. M. McConnell, R. G. Roosen, Z. Sekanina, A. E. Simonenko and G. W Wetherill.

\section{CONSULTANTS}

Recommendations for consultants to the Commission are to be forwarded to the new President within three months.

\section{REORGANIZATION}

The proposals on reorganization of Commissions 15, 16, 20,21, and 22 as presented in the interim report of the General Secretary were approved unanimously. It was further agreed that the General Secretary be informed that the topics of meteorite craters and tektites should be retained within Commission 22.

\section{COMMITTEES}

It was agreed that, as a consequence of the reorganization of Commissions 15 and 22 , and the specific inclusion of the words 'interplanetary dust' in the title of Commission 22, the two existing committees be abolished. 


\section{ZLIM CONFERENCE}

The Commission agreed to the proposal to co-sponsor, with Commission 21, a conference on the 'Zodiacal Light and Interplanetary Medium' to be held in Heidelberg in 1974 or 1975.

\section{METEORITE NOMENCLATURE}

It was agreed to support the establishment of a committee on meteorite nomenclature as proposed by the Meteoritical Society.

TEPEXITL CRATER

Dr Paris Pişmiş has supplied the Commission with preliminary information on a newly recognized meteorite crater in Puebla, Mexico. The structure is $1180 \mathrm{~m}$ in diameter, 65 to $92 \mathrm{~m}$ in depth and the rim is from 18 to $35 \mathrm{~m}$ high. This was proposed as a probable meteorite crater by Lucrecia Manpome in 1972. A full report will be published in Bol. Obs. Tonantzintla y Tacubaya. The Commission congratulates Mrs Manpome on this exciting discovery and recommends that investigation be continued.

A committee on Radar Observations of Meteor Flux and Radiants, and Anomalies at the Base of the Thermosphere was established to investigate the value of and the optimum methods for making world wide observations. The committee consists of: Keay (Chairman), Elford, Kaiser, Lindblad, McIntosh, Verniani. 